\title{
Investigation of Relationship Between Reactive Agility and Cognitive Parameters in Male Football Players
}

\author{
Yakup AKTAŞ ${ }^{1}$ \\ ${ }^{1}$ School of Physical Education and Sports, Harran University, Şanlıurfa, Turkey \\ Correspondence: Yakup Aktaş, Harran University, School of Physical Education and Sports, Şanlıurfa, Turkey. \\ E-mail: yakupaktas@harran.edu.tr
}

Received: May 20, 2019

Accepted: June 14, 2019 Online Published: July 4, 2019

doi:10.5539/jel.v8n4p58

URL: https://doi.org/10.5539/jel.v8n4p58

\begin{abstract}
Objective: This study aims at investigating the relationship between reactive agility and cognitive performance of amateur male football players.

Material and Method: Twenty-four male football players from 11 Nisan Sports Club in Şanlıurfa struggling in Regional Amateur Football League (BAL) participated in the study voluntarily. The mean age, height and weight of the football players participating in the study were $22.88 \pm 4.15$ year, $176.76 \pm 5.90 \mathrm{~cm}$ and $69.76 \pm 7.61 \mathrm{~kg}$, respectively. Psycho-Technical Vienna system was used for Participants' Cognitive tests, IQ (SPM), Continuous Attention (SIGNAL, SIGINAL TIME), Visual Memory (TAVTB), Determination Test (DT, DT TIME), Attention and Problem Solving (COG), Line Tracking (LVT), and Speed Distance Estimation (HMT). For the reactive agility test, the Fusion Sport Smart Speed device was used. Correlation statistics were used for the relationships between the variables. SPSS 23.0 package program was used for statistical operations. For the interpretation of statistical analyze, the significance level was accepted as 0.05 .

Results: There was no significant relationship between IQ (SPM), Continuous Attention (SIGNAL), Visual Memory (TAVTMB), Determination Test (DT), Attention and Problem Solving (COG), Line Tracking (LVT) with reactive agility values of male football players $(p>0.05)$, a significant relationship was found between Continuous Attention Reaction Time (SIGINAL TIME) the rRaction Time of the Determination test (DT TIME) and Speed Distance Estimation (HMT) $(\mathrm{p}<0.05)$.

Conclusion: As the content of the reactive agility test was based only on the speed and reaction speed against light and noise, it was found that the players were only associated with speed distance estimation and response time among the reactive agility performance and the cognitive tests. In order to determine the relationship between reactive agility and cognitive performance, there is a need for new reactive agility tests which are designed according to the branches where there is a distinction between competitor and team player requiring visual memory, attention, reaction, and double action skills.
\end{abstract}

Keywords: football, reactive agility, cognitive test, vienna test

\section{Introduction}

Football is a branch consisting of high intensity, intermittent exercises that requires multiple sprint, negative and positive acceleration, jump and agility in different severity and duration, despite resembling to aerobic (Shephard, 1999). Agility is necessary for a superior performance in football as in many other branches (Ellis et al., 2000). Agility has different definitions in the literature. Agility is considered as the ability to stop, accelerate and change direction suddenly. Many skills in football also include sudden and fast direction changes (Little \& Willams, 2005). Hazar (2005) describes the agility as rapid implementation of a skill. Agility is the effective application of deflection, sudden stop and acceleration, while providing motor control in the vertical or horizontal directions of the body (Verstegen, 2001). Agility is an important feature in the branches such as rugby, volleyball, football including open skills and is a key component for a successful performance (Wheeler, 2009). The agility that is described as open skill exercises based on acquiring information about an object or competitor and effective deflection skill is defined in two categories as planned and reactive in the literature (Farrow et al., 2005).

Planned agility movements are closed skill studies that the start and end and where deflection is supposed to 
happen is known (Oliver \& Meyers, 2009). Reactive agility is open skills studies that include cognitive features consisting of perceptual and decision-making factors, as well motoric features (Serpell et al., 2001; Jeffreys et al., 2011). In addition to these definitions, Sheppard et al. (2006) stated in their studies summarizing the agility literature that the classic definition of agility, which describes the agility as rapid deflection, does not correspond to the agility performance clearly. They collected the agility components under two headings as speed of direction change (technical, flat speed, physical and physical factors including leg strength and anthropometric properties) and perceptual and decision-making factors (visual screening, status information, model recognition and mental factors such as estimation) (Figure 1).

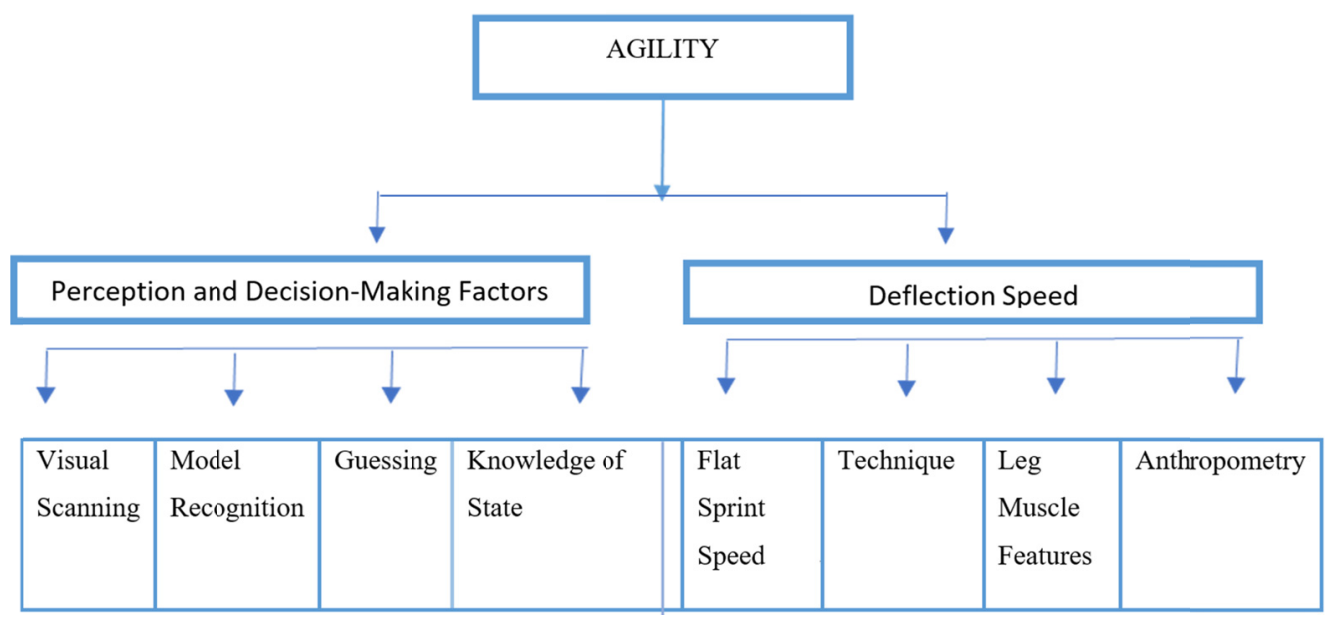

Figure 1. Components of agility (Sheppard et al., 2006)

Decision making: Nowadays, many branches have come to a state of becoming faster and more technical and tactical. During the match, the dynamics of the game may need to change, and the game players may have to make new decisions because of unexpected changes in the game especially in the branches requiring a ball or rallies. The decision means choosing one of the different movements in the game consciously (Sanchez et al., 2009). Decision making is also defined as the process of reducing uncertainties while making reasonable choices between preferences (Tekin et al., 2009).

Reaction: When studied in the literature, it is defined as a suitable motoric response given quickly to one or more stimuli (Çimen, 1994). The reaction time is related to the ability of the players under pressure of space, time and opponent to decide quickly and is an important factor affecting the performance (Konte, 1997).

Attention: The attention is that a person concentrates on the stimuli with their sensory organs exogenously or endogenously. Inattention is being unable to concentrate against these stimuli and not being able to react at any time (İkizler, 1994). At the same time, attention is a conscious and intense perception towards the target (Küçük, 2009).

\section{Material and Method}

\subsection{Participants}

Twenty-four male football player from 11 Nisan Sports Club in Şanliurfa struggling in Regional Amateur Football League (BAL) participated in the study voluntarily. The mean age, height and weight of the participants were shown in Table 1.

Table 1. The mean age, height and weight of the amateur male football players

\begin{tabular}{lllll}
\hline Parameters (24) & Mean & Min. & Max. & Std. \\
\hline Age (years) & 22.88 & 18.00 & 34.00 & 4.04 \\
Height (cm) & 176.76 & 160.00 & 185.00 & 6.02 \\
Weight (kg) & 69.7600 & 51.00 & 82.00 & 7.37 \\
\hline
\end{tabular}




\subsection{Data Collection Tool}

\subsubsection{Reactive Agility}

SmartSpeed (SmartSpeed, FusionSport, Australia) developed by Fusion Sport was used for reactive agility measurement. There are 4 doors with photoelectric cell, light and sound in the track. After the first door, there is a second door at a distance of 5 meters. After that, 2 doors are placed at a distance of 5 meters on the right and left. The participants were supposed to start from one meter backwards of the entrance door and pass by the first and second door and they were asked to run to that direction suddenly and rapidly when they hear a light stimulus or sound stimulus from which of left and right doors (Figure 2). The best results were recorded after 3 repetitions.

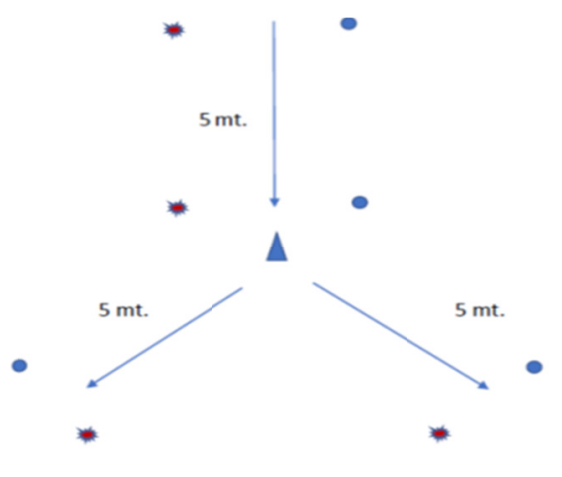

Figure 2. Reactive agility test

\subsubsection{Cognitive Tests}

In the cognitive tests of the participants, Psycho-Technical Vienna system was used for IQ (SPM), Continuous Attention (SIGAL, SIGNAL TIME), Visual Memory (TAVTMB), Determination Test (DT, DT TIME), Attention and Problem Solving (COG), Line Tracking (LVT), Speed Distance Estimation (HMT) tests.

Psychotechnics Vienna Test System is a computer aided psychotechnical measurement and evaluation system developed by Austrian Dr. Schuhfried Ges. m.bH foundation and used to determine the cognitive characteristics and psychomotor skills of individuals (Schuhfried, 2009).

IQ (Spm): This test, based on the understanding and realization of the relationships between abstract visual shapes, measures the reasoning ability of individuals.

Continuous Attention (Signal): In this test, the selective attention level of the candidate was measured by asking the candidate to differentiate certain stimuli from the complex stimuli.

Determination Test (DT): In this test, the correct responses of the candidates and the speed of these responses for visual stimuli of different colours and different tones of acoustic stimuli are measured. In a sudden and panic situation, how fast and how well the candidate could react was measured.

Attention and Problem Solving (Cog): Continuous attention performance of the candidate is measured in this test. In the test, a total of 5 shapes are shown on the screen to the candidates, as 4 of them are above the screen and one of them is below the screen. What is expected from the candidates is that they quickly decide whether the figure given below is the same as one of the above figures.

Visual Memory (Tavtmb): It is a test that measures the visual perception performance and the perceptual speed after showing images about the photograph shown in short time (1 second).

Line Tracking (Lvt): In an environment with complex images, it means leading the attention on a certain direction in a controlled manner.

Speed and Distance Estimation (Hmt): In this test, the ability of the candidate to estimate the movement speed of the stimuli and the distance between stimuli is measured. In this test, the ability of a person to predict moving speed of an object moving and its distance to a target is measured (Schuhfried, 2009).

Data Analysis: Spearman correlation statistics were applied for the relationships between variables in the measurements applied to the participants. SPSS 23.0 package program was used for statistical analyze and significance level was considered as $\mathrm{p}<0.05$ in interpreting the operations. 
This study was approved by Health Sciences Ethics Committee of Harran University Rectorate with the decision dated 16.11.2018 and numbered 2011.5.1/2 in terms of compliance with ethical rules.

\section{Results}

Table 2. The relationship between reactive agility performance and cognitive parameters of male football players

\begin{tabular}{|c|c|c|c|c|}
\hline Parameters & $\mathrm{N}$ & Average & Std. & Reactive Agility \\
\hline Spm & 24 & 79.70 & 9.91 & -.155 \\
\hline $\mathrm{P}$ & & & & 0.468 \\
\hline Signal & 24 & 47.25 & 6.08 & -.204 \\
\hline $\mathrm{P}$ & & & & 0.339 \\
\hline Signal Time & 24 & 0.71 & 0.16 & $.474 *$ \\
\hline $\mathrm{P}$ & & & & $0.019 *$ \\
\hline Tavtmb & 24 & 47.00 & 6.05 & .349 \\
\hline $\mathrm{P}$ & & & & 0.094 \\
\hline Dt Right & 24 & 51.00 & 6.01 & -.076 \\
\hline $\mathrm{P}$ & & & & 0.723 \\
\hline Dt Time & 24 & 0.74 & 0.04 & $.460 *$ \\
\hline $\mathrm{P}$ & & & & $0.024 *$ \\
\hline Lvt & 24 & 51.95 & 6.61 & -.287 \\
\hline$P$ & & & & 0.174 \\
\hline $\operatorname{Cog}$ & 24 & 55.62 & 7.50 & -.032 \\
\hline$P$ & & & & 0.882 \\
\hline $\mathrm{Hmt}$ & 24 & 47.95 & 16.0 & $.408 *$ \\
\hline$P$ & & & & 0.048* \\
\hline
\end{tabular}

Note. ${ }^{*} \mathrm{p}<0.05$

When Table 2 is examined, there was no significant relationship between the reactive agility values of male football players participating in the study and IQ (SPM), Continuous Attention (signal), Visual Memory (TAVTMB) Determination Test (DT), Attention and Problem Solving (COG), and the Line Tracking ( $\mathrm{p}>0.05)$. However, a significant relationship was found between Continuous Attention Time (SIGNAL TIME), Determining Test Time (DT TIME) and Speed Distance Estimation (HMT) $(\mathrm{p}<0.05)$.

\section{Discussion and Result}

In this study; it was aimed to investigate the relationship between reactive agility performance of the football players and cognitive components affecting agility.

When looked at the studies about the agility in the literature, there are many studies investigating the components affecting the deflection speed of the agility. In these studies, it is stated that there is a relationship between the agility and speed, power and anthropometry values being those from deflection factors. In the studies conducted, it was found that there was a relationship mostly between the agility and physical parameters of deflection speed (Pauole et al., 2000; Leone et al., 2002; Cochrane et al., 2004; Okur, 2011; Jovanovic et al., 2011; Sütcü, 2013; Spiteri et al., 2014; Spiteri et al., 2015; Mann et al., 2016; Sayar, 2018).

For a successful performance, a person must have well cognitive characteristics such as predictive and decision-making skills as well as good physical properties (Abemathy, 1999). The fact that the reaction time is short is important when we move to a stimulus or when we react earlier than our competitors do. The importance of reaction time may vary according to the branches (Boyar, 2013).

In the studies conducted, it can be seen that the reaction time of the experienced or inexperienced athletes in different sports branches are discussed intensely. When looked at the studies about these characteristics, which are important for team performance and success, Özmerdivenli et al. (2004) found in their studies comparing the reaction time of the athletes and sedentary against the light and sound reaction that the difference between the participants' response to light and sound stimuli were meaningful in favour of athletes. In his study using the Vienna test system, Zwierko (2007) found that the reaction time of the handball players was shorter than sedantery people. In their studies about the relationship between the reaction time in athletes in different branches (football, basketball, judo, athletics, taekwondo), Atan and Akyol (2014) found that football players have a better reaction than other sport branches.

In their studies investigating perceptual and cognitive skills of elite and non-elite footballers during high 
intensity and low intensity exercise, Martins et al. (2014) found that the number of correct reactions of elite footballers during the low intensity exercise was significantly higher than the non-elite players.

The studies investigating the relationship between reactive agility and cognitive parameters of footballers such as perception and decision making are limited. In the study about female volleyball players, Aktas (2015), determined that there was a relationship between female volleyball players' agility performance and perception, decision-making parameters, the number of correct responses (DT accurate number), accurate response time (DT time), speed distance estimation (HMT), binary processing ability and viewing angle values, but there was no statistically significant relationship between visual perception (TAVTMB) and reasoning (SPM) values. Nimmerichter et al. (2016) found in their study conducted about eighteen young male footballers that their performance of reactive agility developed after 6 weeks of video-based training and there was a a significant relationship between the reaction speed. Young and Willey (2010) determined in their study about 31 male football players that there was a significant relationship between the total time of the reactive agility test and the response time to the stimulus. When looked at the studies conducted, there is a significant relationship between reactive agility, cognitive parameters, reaction and reaction speed. It can be seen that these results are in parallel with the results of our study.

As a result, it is seen in the new definition of agility in the literature that the agility includes the cognitive features such as perception and decision-making features, and visual screening, intuition, and knowledge of status. When looked at the results obtained from the study, it is seen that there is a relationship between the reactive agility of the male footballers and the response time, and speed distance estimation parameters being those from the cognitive factors affecting it, but there is no relationship between the continuous attention, visual memory, bilateral relationship test, attention and problem solving parameters. It is thought that this result is based on the fact that the reactive agility test content implemented in the study is based only on the speed and reaction speed against the light, and the fact that the athlete knows that he will go to one of only two choices after passing through the photocell (50\% estimate).

In order to determine the relationship between reactive agility and cognitive performance, it is necessary to design new reactive agility tests that are designed according to the branches, in which there is a distinction between competitor and team player and requires visual memory, attention, reaction, and double action skills.

\section{References}

Abemathy, B., Wood, M. J., \& Parks, S. (1999). Can the Anticipatory Skills of An Expert be Learned by Novices? Research Quarterly for Exercise and Sport, 70, 326-345. https://doi.org/10.1080/02701367.1999.10608050

Aktaş, Y. (2015). Algl ve Karar Verme Mekanizmalarının Elit Bayan Voleybolcularda Çeviklik Performanslarına Etkisi. Celal Bayar Üniversitesi Sağllk Bilimleri Enstitüsü Spor Bilimleri Anabilim Dalı. Doktora Tezi. Manisa.

Atan, T., \& Akyol, P. (2014). Reaction Times of Different Branch Athletes and Correlation Between Reaction Time Parameters. Procedia - Social and Behavioral Sciences, 116, 2886-2889. https://doi.org/10.1016/j.sbspro.2014.01.674

Boyar, H. (2013). Futbol Branşına Katılan 9-14 Yaş Grubu Erkek Çocuklarının Işšk Reaksiyon Zamanlarının Değerlendirilmesi. Selçuk Üniversitesi Sağlık Bilimleri Enstitüsü. Yüksek Lisans Tezi, Konya.

Ellis, L., Gastin, P., Lawrence, S., Savage, B., Buckeridge, A., \& Stapff, A. (2000). Protocols for physiological assessment of team sports players (pp. 128-144). Physiological Tests for Elite Athletes. CJ. Gore, der. Champaign: Human Kinetics.

Farrow, D., Young, W., \& Bruce, L. (2005). The development of a test of reactive agility for netball: A new methodology. Journal of Science and Medicine in Sport, 8(1), 52-60. https://doi.org/10.1016/S1440-2440(05)80024-6

Jeffreys, I. A. (2011). Task-BasedApproachto DevelopingContext-SpecificAgility. Strength and Conditioning. Journal of Science and Medicine in Sport, 8(1), 52-60. https://doi.org/10.1519/SSC.0b013e318222932a

Jovanovic, M., Sporis, G., Omrcen, D., \& Fiorentini, F. (2011). Effects of speed, agility, quickness training method on power performance in elite soccer players. The Journal of Strength \& Conditioning Research, 25(5), 1285-1292. https://doi.org/10.1519/JSC.0b013e3181d67c65

Küçük, V. (2009). Futbolda Yetenek Seçimi TFF FGM Futbol Eğitim Yayınları (Sayı 4, pp. 49-50). İstanbul.

Little, T., \& Williams, A. G. (2005). Specificity of acceleration, maximum speed, and agility in professional 
soccer players. Journal of Strength and Conditioning Research, 19(1), $76-78$. https://doi.org/10.1519/14253.1

Mann, J. B., Ivey, P. A., Mayhew, J. L., Schumacher, R. M., \& Brechue, W. F. (2016). Relationship Between Agility Tests and Short Sprints: Reliability and Smallest Worthwhile Difference in National Collegiate Athletic Association Division-I Football Players. The Journal of Strength \& Conditioning Research, 30(4), 893-900. https://doi.org/10.1519/JSC.0000000000001329

Martins, F., Garganta, J., Oliveira, J., \& Casanova, F. (2014). The Contribution of Perceptual and Cognitive Skills in Anticipation Performance of Elite and Non-Elite Soccer Players. International Journal of Sports Science, 4(5), 143-151.

Nimmerichter, A., Weber, N. J. R., Wirth, K., \& Haller, A. (2016). Effects of Video-Based Visual Training on Decision- Making and Reactive Agility in Adolescent Football Players. Sports, 4, 1. https://doi.org/10.3390/sports4010001

Oliver, J., \& Meyers, R. W. (2009). Reliability and generality of measures of acceleration, planned agility, and reactive agility. International Journal of Sports Physiology Performance, 4(3), 345-354. https://doi.org/10.1123/ijspp.4.3.345

Özmerdivenli, R., Öztürk, A., \& Karacabey, K. (2004). Sporcu ve sadenterlerin reaksiyon zamanlarının karşılaştırılması ve egzersizin bazı fizyolojik parametrelere etkisi. Doğu Anadolu Bölgesi Araştırmaları Fırat Üniversitesi Beden Eğitimi ve Spor Yüksekokulu, Elazı̆̆.

Sayar, K. E. (2018). U16 Yaş Amatör Genç Erkek Futbolcularda 8 Haftalık Çeviklik ve Pliometrik Antrenmanlarının Aerobik ve Anaerobik Güç Üzerine Etkisi. İstanbul Gelişim Üniversitesi Sağlık Bilimleri Enstitüsü, Yüksek Lisans Tezi, İstanbul.

Serpell, B. G., Young, W. B., \& Ford, M. (2011). Are the perceptual and decision-making components of agility trainable? A preliminary investigation. The Journal of Strength and Conditioning Research, 25(5), 1240. https://doi.org/10.1519/JSC.0b013e3181d682e6

Shephard, R. J. (1999). Biology and medicine of soccer, an update. Journal of Sports Sciences, 17, $757-786$. https://doi.org/10.1080/026404199365498

Spiteri, T., Newton, R. U., Binetti, M., Hart, N. H., Sheppard, J. M., \& Nimphius, S. (2015). Mechanical determinants of faster change of direction and agility performance in female basketball athletes. The Journal of Strength \& Conditioning Research, 29(8), 2205-2214. https://doi.org/10.1519/JSC.0000000000000876

Spiteri, T., Nimphius, S., Hart, N. H., Specos, C., Sheppard, J. M., \& Newton, R. U. (2014). Contribution of strength characteristics to change of direction and agility performance in female basketball athletes. The Journal of Strength \& Conditioning Research, 28(9), 2415-2423. https://doi.org/10.1519/JSC.0000000000000547

Sütcü, B. S. (2013). Futbolda Yön Değiştirme Hız Bileşenleri ve Çeviklik Performansı Arasındaki İlişki. Celal Bayar Üniversitesi Sağlık Bilimleri Enstitüsü, Yüksek Lisans Tezi, Haziran.

Verstegen, M., \& Marcello, B. (2001). Agility and coordination. High Performance Sports Conditioning, 139165.

Young, W. B., James, R., \& Montgomery, I. (2002). Is muscle power related to running speed with changes of direction? Journal of Sports Medicine and Physical Fitness, 43, 282-288.

Young, W. B., \& Willey, B. (2010). Analysis of a reactive agility field test. Journal of Science and Medicine in Sport, 13(3), 376-378. https://doi.org/10.1016/j.jsams.2009.05.006

Zwierko, T. (2007). Differences in Peripheral Perception between Athletes and Nonathletes. Journal of Human Kinetics, 19, 53-62. https://doi.org/10.2478/v10078-008-0004-z

\section{Copyrights}

Copyright for this article is retained by the author, with first publication rights granted to the journal.

This is an open-access article distributed under the terms and conditions of the Creative Commons Attribution license (http://creativecommons.org/licenses/by/4.0/). 